\title{
ANALYSIS OF FAMILY LABOUR UTILIZATION IN THE PRODUCTION OF SELECTED CROPS IN DRY-LANDS: EVIDENCE FROM KAHUTU, KATSINA STATE, NIGERIA
}

\author{
Yusuf, Isah Maikudi \\ Department of Economics \\ Ahmadu Bello University, Zaria \\ iyusuf94@gmail.com
}

\begin{abstract}
Employment on family farms plays an important socio-economic role in dry-land agrarian economies. Given the cropping system, information on the utilization of family farm labour in various crop production activities is an important first step in suggesting measures that could improve its use-efficiency. Guided by a conceptual framework for the analysis of factors influencing the management decision of family farm labour, this paper presents empirical evidence on the utilization of family farm labour in various crop production activities. The analysis is based on survey data collected in 2013 from a sample of 118 farm households that were systematically selected from a population of 5290 households in Kahutu village, Katsina State, Nigeria. Descriptive statistical method using bar charts show that family farm labour utilization measured in average man-days per hectare is highest in May (for maize production), June (for rice production) and July (for sorghum production). On the other hand, the months of June (for maize production), August (for sorghum production) and April (for rice production) have the least family farm labour use. Moreover, weeding requires the highest average man-days per hectare in the cultivation of maize $(>8)$ and sorghum $(\approx 10)$. However, for rice production, land preparation has the highest ( $\approx 7$ man-days). Therefore, ways to mechanize weeding and land preparation for these crops should be explored by government in collaboration with key stakeholders
\end{abstract}

Key Words: Crop Production Tasks, Family Farm Labour, Dry-lands. 


\section{INTRODUCTION}

The family farm is a common feature that cuts across various agricultural structures and plays a critical role in food production systems (Graeub et al., 2016). Family farms are the main form of agricultural organization worldwide, accounting for almost $80 \%$ of global food production, and $98 \%$ of food production in Sub-Saharan Africa (Bélières et al., 2015). Covering around $40 \%$ of the planet's agricultural land, family farms are the number one source of employment worldwide, and they also paradoxically account for the majority of farmers living in poverty and food insecurity (Bélières et al., 2015). Expectedly, employment on family farms also play an important socioeconomic role in dry-land agrarian regions in which family farm labour is one of the key factors of production as well as a source of rural livelihood (Canwat, 2012). CGIAR (2015) reports that there are 1.6 billion people living in rural dry-lands of the developing world, indicating the importance of employment on family farms.

Different family farm ${ }^{1}$, crops and seasons have different labour requirements. Similarly, differences in climate and weather patterns determine when and on which farm activity labour needs are to be concentrated (Salm and Lanting, 2011). Generally, farmers in dry-land tropical regions require more labour time for water management and conservation, while temperate zones have distinct on and off farming seasons (Salm and Lanting, 2011). Whether the farm is intensive or extensive, the degree of access to farm inputs as well as the distribution of labour requirements over the cropping season could also increase or decrease (family) labour use, depending on the man-hours put into the various crop production activities (Salm and Lanting, 2011). As saving on labour time and effort are the major considerations in dry-land farm management (Ogungbile et al., 1998), farmers usually weigh the availability of labour over the season when they make decisions on which crops to plant and the amount of area to cultivate (Salm and Lanting, 2011). Figure 1 shows the different ways in which family farms could meet their labour needs for crop production activities.

\footnotetext{
${ }^{1}$ The FAO (2014) defined family farming as "a means of organizing agricultural, forestry, fisheries, pastoral and aquaculture production which is managed and operated by a family and predominantly reliant on family labor, including both women's and men's. The family and the farm are linked, co-evolve and combine economic, environmental, social and cultural functions."
} 


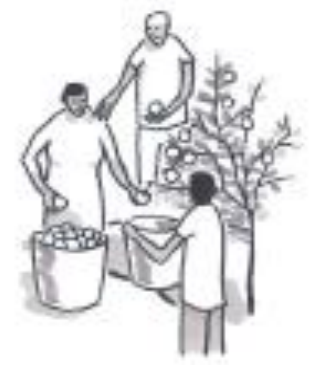

Labour exchange groups

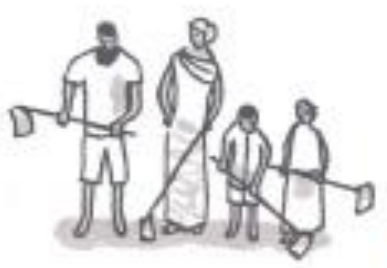

Farm family labour

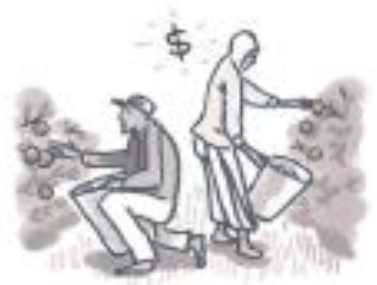

Hired labourers

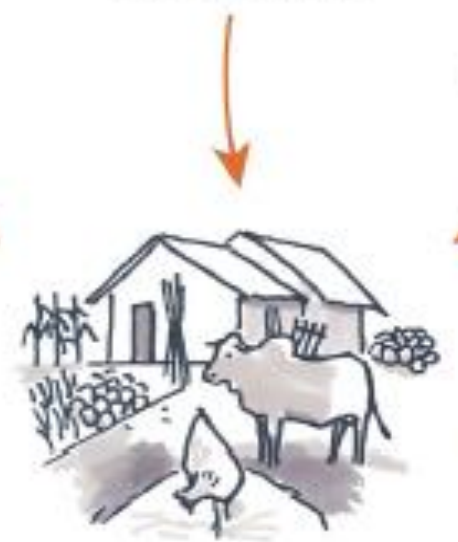

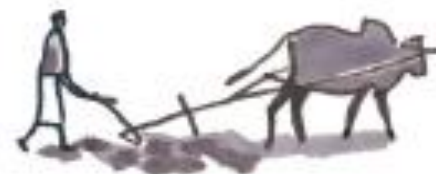

Animal draught power
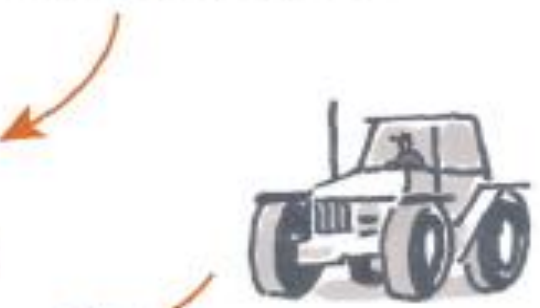

Mechanised power

\section{Figure 1: Different ways to meet labour needs on Family Farms}

Source: Salm and Lanting, 2011

Besides the predictable oscillation in labour utilization, managing a farm well requires constantly being able to respond to changing weather conditions, pest and diseases outbreaks, or even market-related changes that require quick decisions ${ }^{2}$. Although family farms could have adequate labour within the family to cover day-to-day operations, peak periods of labour demand such as land preparation, sowing, transplanting, weeding, harvesting and threshing may necessitate getting outside help (Salm and Lanting, 2011).

\footnotetext{
${ }^{2}$ To a large extent, these decisions also depend on the family farm's priorities and risks of timing actions (Salm and Lanting, 2011). Stone et al., (1990) reported that family farm labour is usually applied within the specific environmental constraint of season, rainfall, soils, differing crop requirements, age and gender. Also, most northern Nigerian farmers seek to save family labour time by owning or hiring ploughs drawn by bulls for ridging both before sowing and in early inter-row weeding.
} 
Given the cropping system, a systematic analysis of the utilization of farm labour visa-vis different crops and crop production tasks is an important first step in understanding labour use related challenges (Ogungbile et al., 1998) and, therefore, suggest policy measures that could improve its use-efficiency. Some of the identified empirical literature in the study region includes Mortimore and Adams (1999) and Mortimore et al., (2000). The studies by Ogbuanya (2000) and Ngeleza et al., (2011) focused on the southern part of Nigeria and Ghana respectively.

Using survey data from Tambau in the Sudano-Sahelian zone of Nigeria, Mortimore and Adams (1999) report that labour allocations to planting, weeding and harvesting, fluctuate during the season and between years. Their findings show that harvesting was divided into two peaks, that is, early millet and cowpeas (first), and sorghum, late cowpeas and groundnuts (second) respectively. Results also indicate that planting work peaked very early while weeding was done three times during the season. Weeding in particular suppressed all other labour tasks and it competes directly with harvesting work later in the season. Mortimore and Adams (1999) concluded that the opportunity costs of different kinds of farm work are constantly held in view as farmers negotiate their way through the growing season. Similarly, Mortimore et al., (2000) report that mechanization of late weeding is not possible due to the height of the grain (likely sorghum or millet) and the practice of inter-cropping with low growing or spreading crops (most likely groundnuts or cowpeas).

In addition, Ogbuanya (2000) examined and compared the economics of labour use under yam and cassava-based cropping systems in Enugu State-Nigeria to provide insight on how farm families optimize the use of available labour resource in production. Survey data results indicate that farmers in both crop enterprises are inefficient in their use of labour, and comparatively, yambased crop farmers are more efficient in their use of labour and other inputs than cassava-based farmers. Ngeleza et al., (2011) assessed the labour requirements in the three major cropping systems in Ghana in order to guide policy on the prioritization of investments in the mechanization of crop production activities. They reported that labour requirements were particularly high in the two cocoa cropping systems in the forest zones as well as for land preparation and crop maintenance. Across crops, land preparation and crop maintenance had the highest share of labour for cassava, yam, and maize production. Rice production also required high shares of labour for land preparation and harvesting. Looking at all the cropping systems, however, crop maintenance required higher labour than land preparation. Thus, this paper contributes to this body of literature and presents empirical evidence on the use of family 
farm labour in various crop production tasks and is organized in four sections, viz: introduction, methodology, results and discussion and conclusive and recommendation.

\section{METHODOLOGY}

This paper is guided by a conceptual model adapted from Chilonda and Huylendbroeck (2001). The model shows how family labour management decisions relate to variables that embody characteristics specific to family farmers and farms, economic factors, institutional settings as well as biophysical factors (see figure 2). To gain an improved understanding of the decision-making process of family farms in the study region, survey data ${ }^{3}$ was collected from a case study village to highlight typical farm size, crops and household characteristics with respect to their human capital and labour requirements measured in average man-days per hectare. Here, man-day is defined as "one person's working time for a day (or its equivalent) usually used as measure of how much work or labour is required or consumed to perform some task"4.

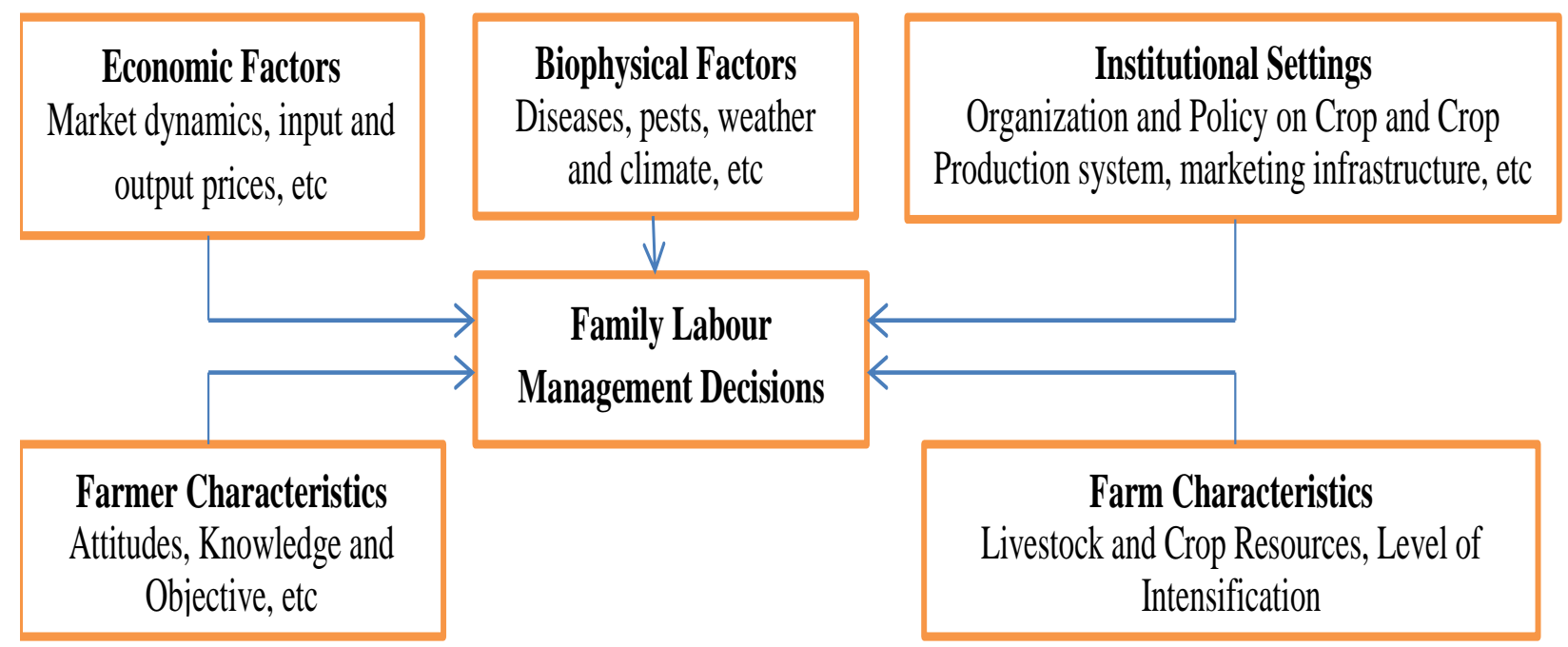

Figure 2: Conceptual Framework for the Analysis of Factors Influencing Management Decision of Family Farm Labour in Crop Production Activities

Source: Adapted from Chilonda and Huylendbroeck (2001)

\footnotetext{
${ }^{3}$ The survey data was collected to complement a PhD thesis research by Yusuf (2016) on the link between Climate Variability, Food Crops Supply and Family Farm Employment in the Sudano-Sahelian Zone of Nigeria. Funding from WASCAL and BMBF for the survey is gratefully acknowledged.

${ }^{4}$ See www.wordnik.com/words/man-day)
} 
Therefore, information was collected for three key crops (maize, sorghum and rice) widely cultivated in the study area focusing on the following crop production tasks, viz: land preparation, planting, fertilization, weeding, harvesting, threshing and spraying. Kahutu village was purposively selected from the Sudan-savanna zone and for other cost and proximity considerations. It is located in Danja Local Government Area of Katsina State with a population of about 5,290 people and majority of them are engaged in rain-fed crop production and livestock rearing as is typical in most dry-land agrarian villages in the study region. A sample size of 118 households was selected from a total of 766 households using systematic random sampling. Every 6th household was selected from the sample frame which was received from the local government authorities. The sample frame was also used for the last immunization exercise in 2013. Bar charts were used to show varying family labour use over the cropping season for three crops with respect to five crop production tasks, that is, land preparation, planting, fertilization, weeding, planting and threshing.

Table 1 General Village Characteristics

\begin{tabular}{lll}
\hline Population & $\begin{array}{l}\text { Persons (estimate) } \\
\text { Households } \\
\text { (estimate) }\end{array}$ & $\begin{array}{l}5290 \\
766\end{array}$ \\
\hline $\begin{array}{l}\text { Village } \\
\text { Structure } \\
\text { Land Tenure }\end{array}$ & $\begin{array}{l}\text { Hamlets } \\
\text { Family Owned Land } \\
\text { Rented or Purchased }\end{array}$ & 14 \\
Agriculture & $\begin{array}{l}\text { Mainly Crop production } \\
\text { and some animal } \\
\text { rearing }\end{array}$ & $\begin{array}{r}\text { Cereals (Maize, Sorghum, Rice, Millet), legumes } \\
\text { (Cowpea, Groundnut), Vegetables (onions, tomatoes, } \\
\text { spinach) animals (Goat, Sheep, Cattle, Chicken) }\end{array}$ \\
\hline
\end{tabular}

Source: Field Survey, 2013

Table 1 summarizes the key characteristics of the village. Crop production is the main source of livelihood in the villages. Although not a major source of livelihood, livestock are also kept by the farmers in the village.

\section{RESULTS AND DISCUSSION}

The analysis of the result of the household survey data collected from the case study village is presented and discussed in this section. The results show the utilization of family farm labour, measured in average man-day per hectare over the cropping season from April to October as 
well as in various crop production activities for each crop. Figure 3 shows the distribution of family labour over months in the cropping season for the production of maize.

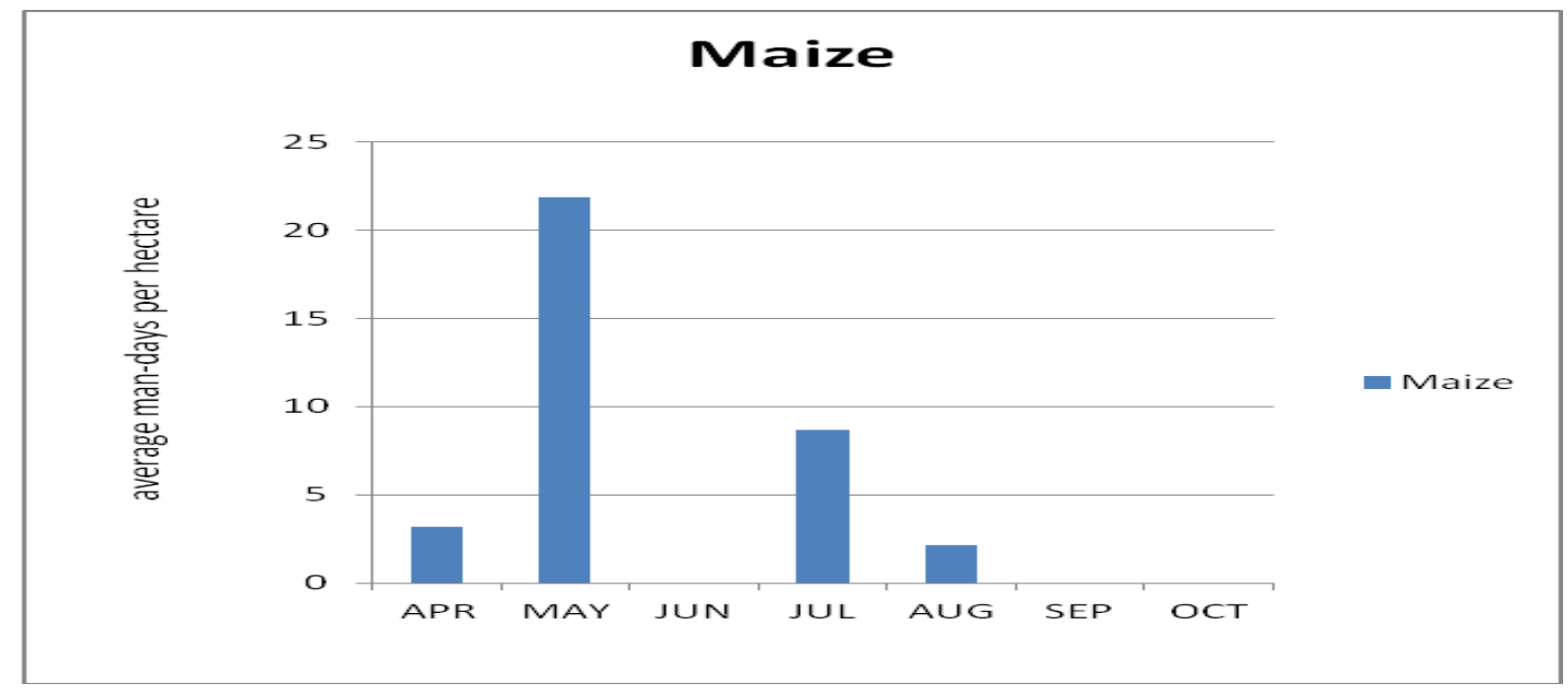

\section{Figure 3: Family Labour Utilization for Maize Production over the Cropping Season}

Source: Field Survey, 2013

Labour use in May and July which coincides with land preparation and planting (May) as well as weeding and fertilizer application (July) are the highest, with average man-days per hectare of over twenty and eight respectively. A study by Leonardo et al., (2015) also found that access to labour during weeding is the most important constraint in maize-based smallholder farming systems in Mozambique.

Figure 4 also depicts family labour use (in man-days per hectare) for the production of maize with respect to varying tasks. Weeding (over eight man-days per hectare), land preparation and harvesting (about six man-days per hectare each) are the tasks which utilize the highest amount of family labour. This is corroborated by Ngeleza et al., (2011) who reported that land preparation and crop maintenance takes the highest labour in maize production in Ghana. Fertilizer application and threshing largely takes place in July and October in the cropping season. Note, however, that figure 3 indicates that relatively little or no family labour is utilized in these months which may imply the reliance on hired labour as against family labour. 


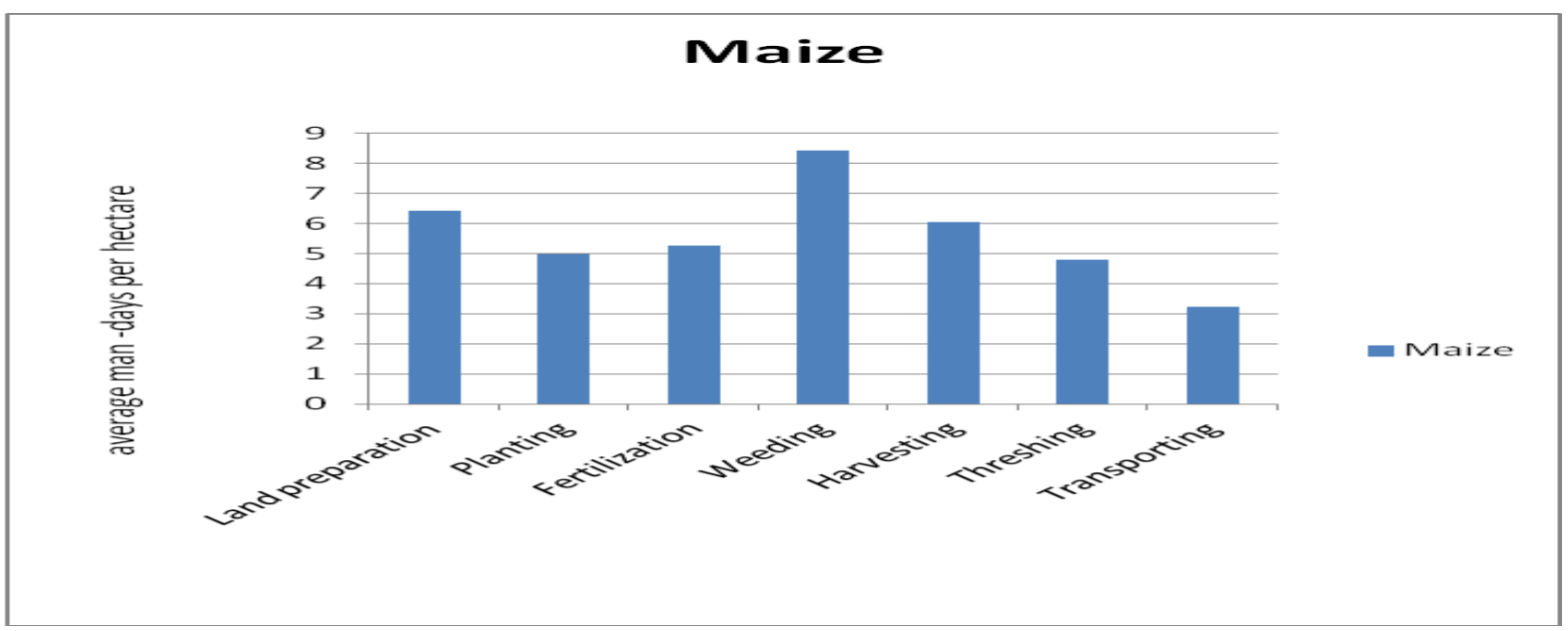

Figure 4: Family Labour Utilization for Maize Production for Various Tasks Source: Field Survey, 2013

Figure 5 and 6 also show the distribution of family labour use in the production of sorghum over the cropping season as well as with respect to various crop production tasks. Bar charts show that May, July and October are the months in which the utilization of family labour is highest, with about six, eleven and nine man-days per hectare respectively. This period coincides with crop production activities such as weeding and fertilizer application, as well as harvesting and threshing.

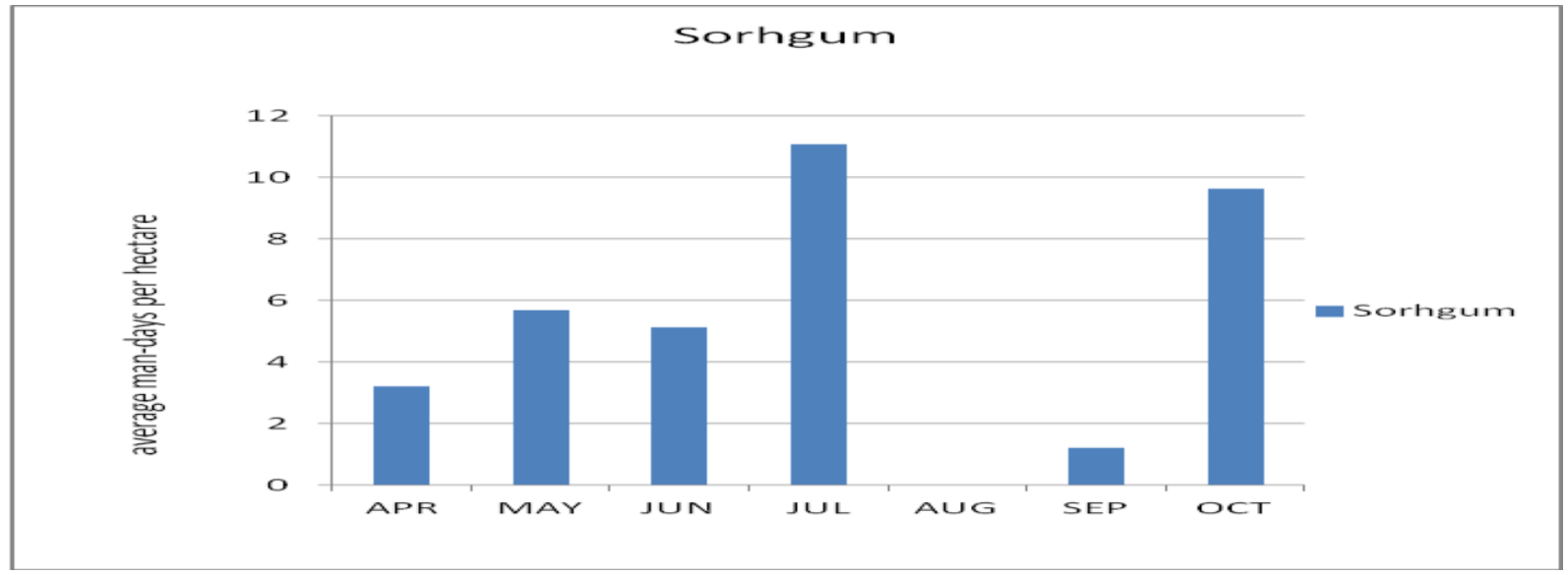

Figure 5: Family Labour Utilization for Sorghum Production over the Cropping Season Source: Field Survey, 2013 
In particular, the finding that weeding which occurs around July takes the highest average mandays per hectare for sorghum corroborates the fact that manual weeding is labour-intensive, accounting for $80 \%$ of the total labour required for producing food in Nigeria (Imoloame, 2014). Land preparation and planting which occurs in April and May also require a significant amount of labour (average of seven and five man-days per hectare respectively) as shown in Figure 6.

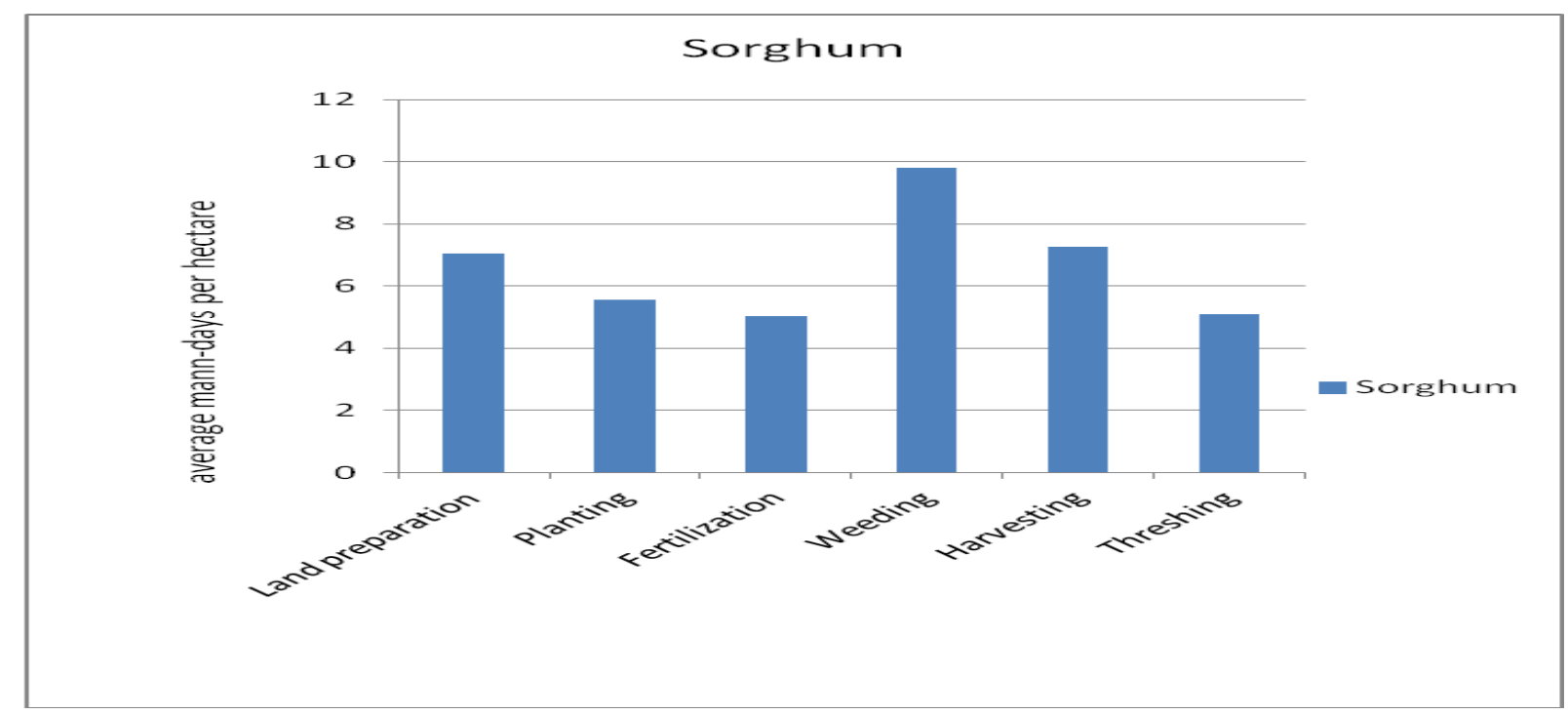

\section{Figure 6: Family Labour Utilization for Sorghum Production by Various Tasks}

Source: Field Survey, 2013.

In the production of rice, Figure 7 shows that May, June and July are the months in which the highest amounts of family labour are used, that is, about six, twelve and five man-days per hectare. These months are the months over which land preparation, planting, fertilizer application and weeding activities are done. In general however, figure 8 indicates that family labour use cuts across all production activities except harvesting and threshing in the production of rice seems to be little or no family labour use in October which corresponds with the production activity of harvesting and threshing. This may be an indication that hired labour is predominantly used for these tasks 


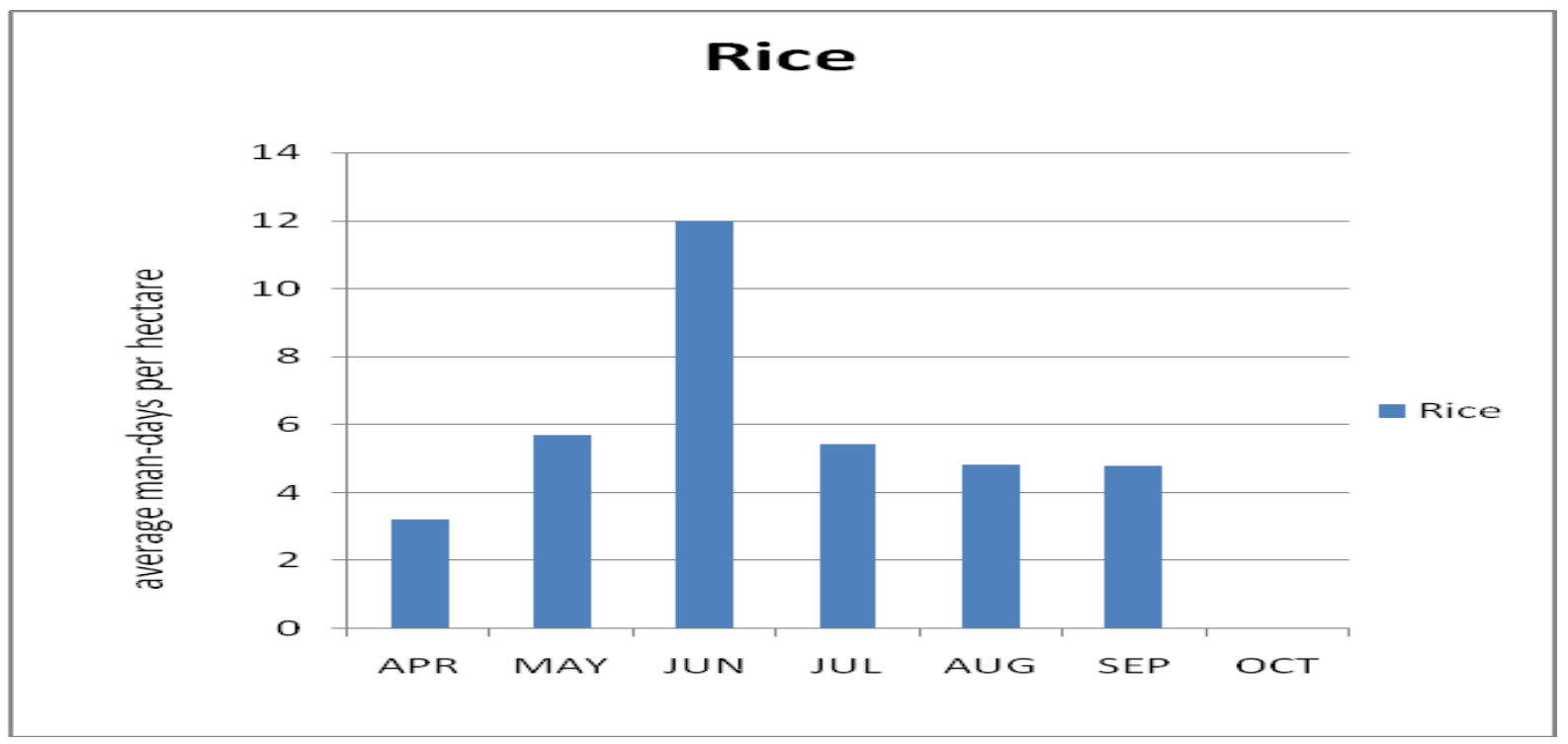

Figure 7: Family Labour Utilization for Rice Production over the Cropping Season Source: Field Survey, 2013

With respect to specific tasks, Figure 8 indicates that land preparation and weeding are the tasks that use the highest amount of family farm labour in terms of man-days per hectare (about seven and six respectively). Planting, fertilizer application and threshing activities use, on the average, about five man-days per hectare. 


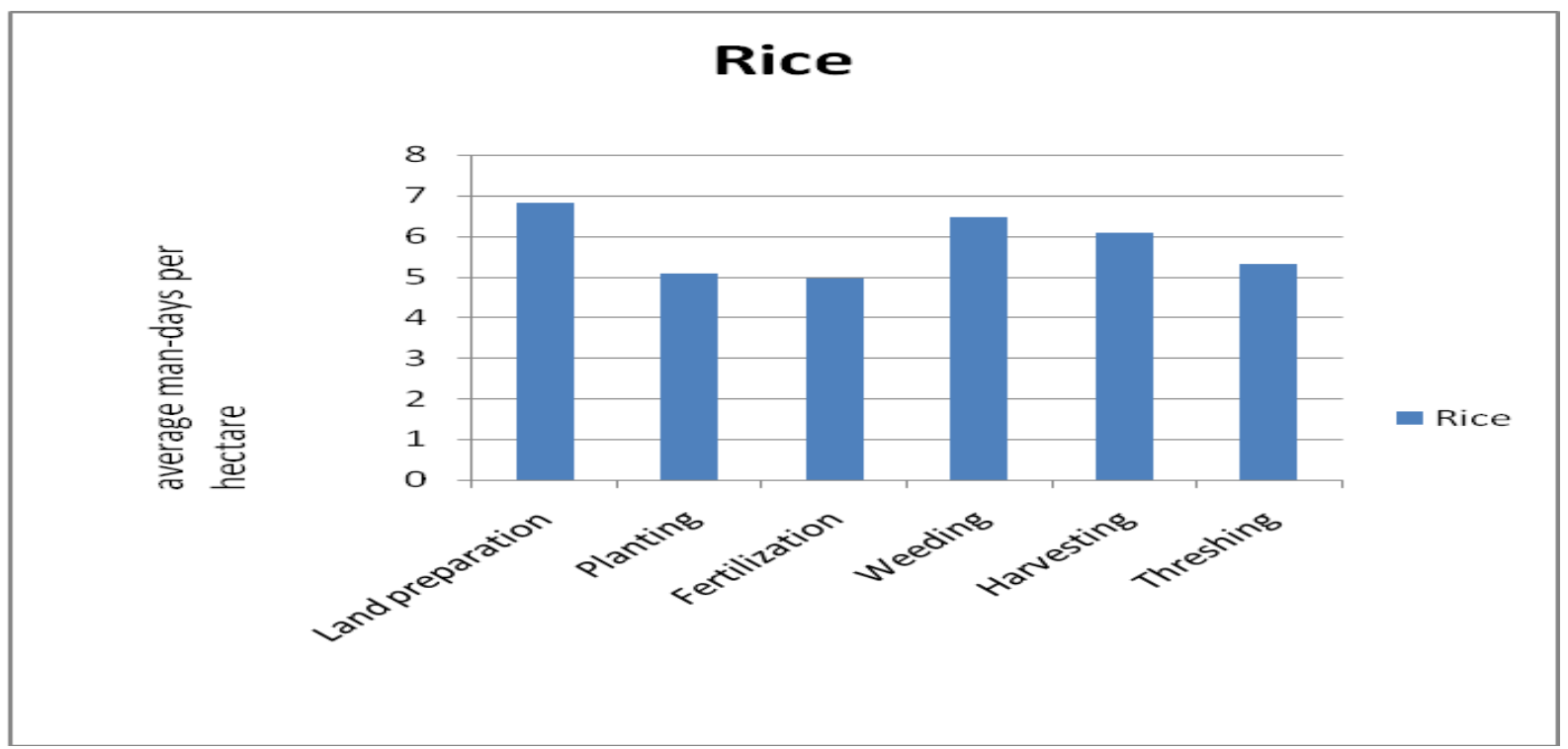

Figure 8: Family Labour Utilization for Rice Production by Various Tasks

Source: Field Survey, 2013

\section{CONCLUSION AND RECOMENDATION}

Labour is one of the most limiting resources in crop production activities in dry-land agriculture. Given that the dominant structures for agricultural production are family farms, this paper investigates the use of family farm labour in six important crop production tasks, using Kahutu village in Kastina State-Nigeria as a case study. In general, results indicate that land preparation and weeding are the dominant crop production task across the three crops and the month of May, June and July are the most critical months in the utilization of family farm labour. This information could form the basis of encouraging family farms to adopt labour saving farming techniques particularly for the task of weeding. Ways to mechanize this task should also be explored by government given its current drive to revamp the agricultural sector in Nigeria. 


\section{REFERENCES}

Bélières, J.F., Bonnal, P., Bosc, P.M., Losch, B., Marzin, J., Sourrisseau, J.M. \& Thirion, M.C. (2015) Family Farming Around the World: Definitions, Contributions and Public Policy, Montpellier, CIRAD \& Paris, Agence Française de Développement

Canwat, V. (2012) "Modeling Seasonal farm Labour Demand: What can we learn from Rural Kakamega District, Western Kenya?" International Journal of Development and Sustainability 1 (2): 195-211

CGIAR Research Program on Dryland Systems (2015) Annual Report 2015: Towards Sustainable livelihoods in Dry-Lands. Amman, Jordan

Chilonda, P. and Van Huylenbroek, G. (2001) "A Conceptual Framework for the Economic Analysis of Factors Influencing Decision-making of Small-scale Farmers in Animal Health Management" Scientific and Technical Review of the Office International des Epizooties (Paris), 20 (3): 687-700 '

FAO (2014) The State of Food and Agriculture 2014: Innovation in Family Farming, Food and Agriculture Organization of the United Nations, Rome

Graeub, B. E., Chappell, M. J., Wittman, H., Ledermann, S., Kerr, R. B., \& Gemmill-Herren, B. (2016) "The State of Family Farms in the World" World Development, 87, 1-15

Leonardo, W. J., van de Ven, G. W. J., Udo, H., Kanellopoulos, A., Sitoe, A., and Giller, K. E. (2015) "Labour not land constrains agricultural production and food self-sufficiency in maize-based smallholder farming systems in Mozambique", Food Sec. 7:857-874

Mortimore, M. and Adams, W. M. (1999) Working the Sahel: Environment and the Society in Northern Nigeria, London: Routledge

Mortimore, M., Adams, W. and Harris, F. (2000) "Poverty and Systems Research in the Drylands" IIED Gatekeeper Series, No. 94

Ngeleza, G. K., Owusua, R., Jimah, K., Kolavalli, S. (2011) "Cropping practices and labor Requirements in field operations for major crops in Ghana: What needs to be Mechanized?", International Food Policy Research Institute Discussion Paper No. 1074, Washington DC

Imoloame, E. O. (2014) "The Effect(s) of Different Weed Control Methods on Weed Infestation, Growth and Yield of Soybeans (Glycine Max (L) Merril) in the Southern Guinea Savanna Of Nigeria" Agrosearch, 14(2):129-143

Ogbuanya, S. U. (2000) Comparative Economics of Labour Use in Yam-and Cassava-Based Cropping System in Enugu State, Unpublished M.Sc. Thesis, Department of Agricultural Economics, University of Nsuka Nigeria 
Ogungbile, A. O., Tabo, R., Van Duivenbooden, N. and Debrah, S. K. (1998) "Analysis of Constraints to Agricultural Production in the Sudan Savanna Zone of Nigeria using MultiScale Characterization" NJAS-Wageningen Journal of Life Sciences, 46 (1): 27-38

Salm, M. and Lanting, M. (2011) "Module 5: Labour and Energy in Small Scale Farming" In: Learning AgriCultures: Insights from Sustainable Small Scale Farming, ILEIA: Netherlands

Stone, G. D., Netting, R. M. and Stone, M. P. (1990) "Seasonality Labor Scheduling and Agricultural Intensification in the Nigerian Savanna" American Anthropologist, 92 (1):7-23

Yusuf, I. M. (2016) Climate Variability, Food Crops Supply and Family Farm Employment in the Sudano-Sahelian Zone of Nigeria, Unpublished PhD Thesis, UCAD 